\title{
The Antimicrobial Effect of Some Selected Nigerian Chewing Sticks on Clinical Isolates of Candida Species
}

\author{
Osho A. ${ }^{1, *}$, Adelani O. A. ${ }^{2}$ \\ ${ }^{1}$ Department of Biological Sciences, Redeemer's University, Mowe, Ogun State \\ ${ }^{2}$ Deparment of Microbiology, OlabisiOnabanjo University, Ago-Iwoye, Ogun State
}

\begin{abstract}
Extracts of selected chewing sticks ( Fagarazan thoxyloides, Anogeissus leiocarpus and Diste moranthus benthamianus ) obtained in Ibadan metropolis, were assayed for their antifungal activities against Candida sp(C. albicans, C. kruseiand C. tropicalis). Aqueous and ethanolic extractions were carried out to obtain the active ingredients of the chewing sticks. The agar diffusion method was used to assay the antifungal activity of the extracts. Both the aqueous and ethanol extracts of all the chewing sticks exhibited inhibitory activity on the growth of C. albicans, C. krusei and C. tropicalis. The zones of inhibition produced by the different extracts against the Candida species were significantly different at standard of mean. Data from the present study have shown the chewing sticks as a potential candidate for the production of dentifrice and other natural products for oral hygiene and treatment of tooth problems.
\end{abstract}

Keywords Nigerianchewing Stick, Clinical Isolates, Antifungal Activities, Inhibitory Activity, Aqueous Extract, Candida

\section{Introduction}

The use of chewing sticks has been documented since ancient times. This kind of tooth brushing has been used by the Babylonians some 7000 years ago[1]. In many traditional cultures, there are no plastic-bristle brushes, rather, the use of herbal chewing sticks for relieving dental problems is common. The cleansing efficacy of chewing sticks is attributed to the mechanical effects of its fibers, release of beneficial chemicals or a combination of both[2]. Some African chewing sticks are also reported to contain fluoride ions, silicon, tannic acid, sodium bicarbonate and other natural plaque inhibiting substances that can reduce bacterial colonization and plaque formation[3]. The repeated process of using chewing sticks releases fresh sap containing fluoride, which seems to wet the tooth enamel and adequately reach caries susceptible sites and contribute towards caries prevention[4]. Tannin exerts an astringent effect on the mucous membrane, thus reducing the clinically detectable gingivitis[5]. Tannins also inhibit the action of glucosyltransferase thus reducing plaque and gingivitis[6]. Resines forms a layer over the enamel and thus protects against caries. Alkaloids exert bactericidal effect in the oral cavity[7]. Essential (volatile) oils possess characteristic aroma and exert antiseptic action[8]. The mild bitter taste sulfur compounds have

* Corresponding author:

adelekeosho@yahoo.com (Osho A.)

Published online at http://journal.sapub.org/ microbiology

Copyright $(\underset{2}{2012}$ Scientific \& Academic Publishing. All Rights Reserved a bactericidal effect[10]. Vitamin $C$ is antioxidant and helps in the healing and repair of tissues. Sodium bicarbonate has mild abrasive properties and is, thus, used as a dentifrice in addition to having a mild germicidal action[11,12]. The high concentrations of chloride inhibit calculus formation[13] and help in removing stains from the teeth [8] Calcium saturation of saliva inhibitsdemineralization and promotes re- mineralization of tooth enamel[6].

A great number of these plant species have related medicinal properties that may be antibacterial[4,3]. D. benthamianusis rich in flavonoid compounds[14], such as oxyayain A, oxyayain B, Ayanin and Distemonanthin. These components have been implicated in antitumor activity, antioxidative activity[15], anti-adrenergic activity[16] and treatment of bacterial, fungal and viral infection[14]. Anogeissusleiocarpus is also another plant species used in traditional medicine as a remedy for many ailments of livestock and man, which include helminthosis, schistomiasis, leprosy, diarrhea and psoriasis[17,18]. In addition to these applications, Hollist[19] reported that A. leiocarpusis one of the major plants commonly used as chewing stick in Nigeria. Fagarazanthoxyloides is also widely distributed in African countries. The root-bark extract is used in treating elephantiasis, toothache, sexual impotence, gonorrhoea, malaria, dysmenorrhoea and abdominal pain [20-22]. Many studies have demonstrated the antimicrobial, anticarries, anti- periopathic and antifungal properties of both aqueous and ethanolic extracts of various chewing sticks[23-26]. There are documented reports on the antimicrobial activity of A. leiocarpuson oralmicroflora.[15]reported the antimicrobial effect of its root extract on Staphylococcus aureus and 
Pseudomononasaeroginosa.[27]documented the antibacterial activity of its bark extract on Bacteriodesgingivalisand Bacteriodesmalaninogenicus. Workers in West Africa have also reported the anti-sickling and antimicrobial activity of the extracts of Fagarazanthoxyloides[28]. Water extracts from the plant showed activities against bacteria significant to periodontal disease[30,24]. The anthelmintic activity of the methanolic extract of the root-bark of F. zanthoxyloides was also reported[31], and it is a very popular anthelmintic amongst the various tribes in Uganda. It has also been found that the alcoholic extracts of the root-bark possesses considerable antibacterial activity[32]. An anti-sickling agent [29] and an anti-inflammatory amide were isolated from the plant[33]. Therefore, this paper examines the inhibitory activity of some selected Nigerian chewing sticks extracts against selected clinical isolates of Candida species.

\section{Materials and Methods}

\section{Collection of Materials}

The chewing sticks (Fagarazanthoxyloides, Anogeissusleiocarpus and Distemoranthusbenthamianus) used were obtained from King's market (Oja Oba) in Ibadan, Oyo state, Nigeria. They were authenticated by a Botanist at the Department of Botany, OlabisiOnabanjo University, AgoIwoye, Ogun State, Nigeria.

\section{Yeast strains}

The modified methods of[34] was employed for the isolation of Candida species. Candida strains were obtained from the oral cavity of healthy young adult from the students of OlabisiOnabanjo University aged between 18 and 26 years. Individual with medical history for candidiasis were selected. Sterile swabs were used to collect clinical specimen from saliva, tongue dorsum, palate mucosa, dental biofilm and denture. The swab was immediately immersed in a tube containing sterile saline and the tube agitated for 30 seconds. $100 \mu \mathrm{l}$ from this clinical specimen was then diluted 10-fold and 100 fold in sterile saline. An aliquot of $100 \mu \mathrm{l}$ from the diluted sample was inoculated in plate containing Sabouraud dextrose agar (Merc Germany), $0.1 \mathrm{mg} / \mathrm{ml}$ chloramphenicol was added to each and duplicates were setup. The plates were incubated at $370 \mathrm{C}$ for $48 \mathrm{~h}$. After incubation, identification of the Candida species was carried out by stan- dard-taxonomic methods which include germ tube production, microscopic appearances on cornmeal agar with Tween-80, pigment production on chromogenic mediun, chlamydospore production and colony morphology. This identification was confirmed with the test kit, API 32 C AUX (bioMerieux, Marcy-l'Etoile, France).

\section{Plant preparation}

The test plant parts were washed in distilled water and air dried at room temperature for two weeks. The dried plant parts were chopped into bits before blending with an electric blender. The blended chewing stick samples was sterilized by autoclaving at $1.02 \mathrm{Kgm}-2$ pressure at $1210 \mathrm{C}$ for 10 minutes and allowed to cool to room temperature before dispensing aseptically into $250 \mathrm{ml}$ Erlenmeyer flask and tapered.

\section{Extraction}

$5 \mathrm{~g}$ each of the chewing stick samples were separately soaked in $100 \mathrm{ml}$ of distilled sterilized water and $95 \%$ ethanol respectively. This was allowed to stand for 7 days for extraction of the active ingredients. The solvents were then filtered using Whatman No1 filter paper. The extracts were then kept in fridge prior to use.

\section{Antifungal Assay}

Agar-well diffusion method was used for the assay. The Candida strains were sub-cultured to obtain a more vigorous population. The fresh stocks were used to seed $20 \mathrm{ml}$ Potato Dextrose broth. Spore suspension of $10^{5}-10^{7}$ cells was prepared and $0.5 \mathrm{ml}$ was used to inoculate prior prepared sterile PDA plates. The $6 \mathrm{~mm}$ diameter cork borer was used to make well on the plates for introduction of different test plants extracts. The plates were incubated and the zone of inhibition was measured in mm after 24 and 48 hours of growth. A control experiment was set up by using sterile distilled water and ethanol differently in place of different extracts of the test plants.

\section{Results}

The results of the antifungal assay are presented in Table 1, 2 and 3. From the present data, it is evident that both the aqueous and ethanol extracts of all the test plant parts exhibited inhibitory activities on the growth of C. albicans, C. krusei and C. tropicalis.

Table 1. Inhibition Zone of Candidaalbicans, C. kruseiand C. tropicalis against Aqueous and Ethanol Extract of Anogeissusleiocarpus

\begin{tabular}{|c|c|c|c|c|c|}
\hline Organisms & $\begin{array}{c}\text { Time of } \\
\text { incubation }(\mathrm{h})\end{array}$ & $\begin{array}{c}\text { Aqueous } \\
\text { Extract (mm) }\end{array}$ & $\begin{array}{c}\text { Ethanol } \\
\text { Extract (mm) }\end{array}$ & $\begin{array}{c}\text { Control } \\
\text { Aqueous(mm) }\end{array}$ & $\begin{array}{c}\text { Control } \\
\text { Ethanol(mm) }\end{array}$ \\
\hline \multirow{2}{*}{ Candida albicans } & 24 & $12 . \pm 1.0$ & $17.0 \pm 0.4$ & $6.00 \pm 0.00$ & $6.00 \pm 0.00$ \\
& 48 & $8.1 \pm 0.8$ & $15.0 \pm 0.8$ & $6.00 \pm 0.00$ & $6.00 \pm 0.00$ \\
\hline C. Krusei & 24 & $15.0 \pm 0.8$ & $20.0 \pm 0.8$ & $6.00 \pm 0.00$ & $6.00 \pm 0.00$ \\
\hline C. tropicalis & 48 & $11.0 \pm 0.9$ & $17.5 \pm 0.8$ & $6.00 \pm 0.00$ & $6.00 \pm 0.00$ \\
\hline
\end{tabular}

Values are standard mean of triplicates 
Table 2. Inhibition Zone of Candidaalbicans, C. kruseiand C. tropicalisagainst Aqueous and Ethanol Extract of Distermoranthusbenthaminaus

\begin{tabular}{|c|c|c|c|c|c|}
\hline Organisms & $\begin{array}{c}\text { Time of incuba- } \\
\text { tion }(\mathrm{h})\end{array}$ & $\begin{array}{c}\text { Aqueous Extract } \\
(\mathrm{mm})\end{array}$ & $\begin{array}{c}\text { Ethanol Ex- } \\
\text { tract }(\mathrm{mm})\end{array}$ & $\begin{array}{c}\text { Control Aque- } \\
\text { ous(mm) }\end{array}$ & $\begin{array}{c}\text { Control Etha- } \\
\text { nol(mm) }\end{array}$ \\
\hline Candida albicans & 24 & $8.2 \pm 1.0$ & $12.0 \pm 0.7$ & $6.00 \pm 0.00$ & $6.00 \pm 0.00$ \\
& 48 & $6.0 \pm 0.8$ & $11.0 \pm 0.9$ & $6.00 \pm 0.00$ & $6.00 \pm 0.00$ \\
\hline C. Krusei & 24 & $6.1 \pm 0.4$ & $9.0 \pm 0.8$ & $6.00 \pm 0.00$ & $6.00 \pm 0.00$ \\
& 48 & $4.0 \pm 0.8$ & $7.0 \pm 0.5$ & $6.00 \pm 0.00$ & $6.00 \pm 0.00$ \\
\hline C. tropilis & 24 & $6.0 \pm 0.0$ & $9.0 \pm 0.8$ & $6.00 \pm 0.00$ & $6.00 \pm 0.00$ \\
\hline
\end{tabular}

Values are standard mean of triplicates

Table 3. Inhibition Zone of Candidaalbicans, C. kruseiand C. tropicalis against aqueous and ethanol extract of Fagarazanthoxyloides

\begin{tabular}{|c|c|c|c|c|c|}
\hline Organisms & $\begin{array}{c}\text { Time of incuba- } \\
\text { tion }(\mathrm{h})\end{array}$ & $\begin{array}{c}\text { Aqueous Ex- } \\
\text { tract }(\mathrm{mm})\end{array}$ & $\begin{array}{c}\text { Ethanol Extract } \\
(\mathrm{mm})\end{array}$ & Control Aqueous(mm) & Control Ethanol(mm) \\
\hline \multirow{2}{*}{ Candida albicans } & 24 & $13.0 \pm 0.8$ & $15.0 \pm 0.8$ & $6.00 \pm 0.00$ & $6.00 \pm 0.00$ \\
& 48 & $11.5 \pm 1.0$ & $12.0 \pm 0.7$ & $6.00 \pm 0.00$ & $6.00 \pm 0.00$ \\
\hline \multirow{2}{*}{ C. Krusei } & 24 & $15.6 \pm 0.9$ & $18.0 \pm 0.8$ & $6.00 \pm 0.00$ & $6.00 \pm 0.00$ \\
& 48 & $14.1 \pm 0.8$ & $16.1 \pm 0.8$ & $6.00 \pm 0.00$ & $6.00 \pm 0.00$ \\
\hline \multirow{2}{*}{ C. tropilis } & 24 & $10.2 \pm 0.6$ & $12.0 \pm 0.7$ & $6.00 \pm 0.00$ & $6.00 \pm 0.00$ \\
& 48 & $7.0 \pm 0.5$ & $9.0 \pm 0.8$ & $6.00 \pm 0.00$ & $6.00 \pm 0.00$ \\
\hline
\end{tabular}

Values are standard mean of triplicates

\section{Discussion and Conclusions}

The results of the antimicrobial assay depict that the aqueous and ethanol extracts of the plant parts demonstrated inhibitory activity on the growth of the three tested fungi. However, these results are contrary to earlier reports [35; $36,37]$ who indicated that there was no activity of A. leiocarpusextract on $\mathrm{C}$. albicans. The contradiction in the results to the earlier reported research could be as result of differences in the concentration of active ingredient in the chewing stick extracts. On the other hand, it could also be attributed to the microbial load used for the anti-fungal assay. All these are capable of bringing about variations in the result. Extracts of F. zanthoxyloideswere completely active against all the fungi tested. The zone of inhibition produced by Fagarazanthoxyloides against $\mathrm{C}$. krusei was more pronounced than the rest of the test fungi. The result is quite contradictory to that of [38] who reported on the lack of effect of $F$. zanthoxyloideson the adherence and growth of the oral opportunist pathogen and that the extracts of F. zanthoxyloideswere completely inactive against all the microbes tested. This could be due to the fact that they tested the extracts against bacterial oral pathogens. A large number of constitutive plant compounds have been reported to have antimicrobial activity. Well known examples include phenols, unsaturated lactones, saponnins, cyanogenic glycosides and glucosinolates[39,40]. Various chemicals such as alkaloids, tannins, saponnins, cyanoglycosides, terpenoids, oleic and stearic acids which are naturally present in plants have been implicated in the conferment of antimicrobial activities on the plant containing them [39, 40, 41].

The presence of these phytochemicals in the investigated test plant parts would be responsible for the demonstrated antimicrobial activity of the different plant extracts. Furthermore, these plant secondary metabolites must have been present in a significant amount in the investigated parts of the plants in order to have been able to confer antimicrobial activity on the extracts of this plant. Previous reports have indicated that the root of A. leiocarpusis often used as chewing stick $[25,15]$. Paradoxically, this study also showed that the stem also contained active agents against the tested oral pathogens, and thus could be used in the absence of the root of this plant. Hence, higher plants, as sources of medicinal compounds continue to play dominant role in maintenance of human health since antiquities. Over $50 \%$ of all modern clinical drugs are of natural product origin [42] and natural products play an important role in drug development programs of the pharmaceutical industry $[43,44]$ In this regard, the use of plants in the production of dentifrice and natural chewing gums for oral hygiene and to treat toothache, gingivitis and periodontal disease has been reported by Kerry [45]. Data from the present study have implicated the plants parts as a potential candidate in such application. It is hoped that this discovery would be utilized to better the oral health of Africans whose landscape is replete with these plants.

\section{REFERENCES}

[1] Al-Sadhan, R. I., Almas, K. 1999. Miswak (chewing stick): A cultural and scientific heritage. Saudi Dent J, 11: 80-8

[2] Hardie, J., Ahmad, K.1995. The miswak as an aid in oral hygiene.J. Phillipp Dent Assoc, 4: 33-38

[3] Evans, W. C. 2002. Trease and Evans' Pharmacognosy.15th ed. W.B. Saunders, London

[4] Almas, K AI-LafiT, A. H. 1995. The effect of the extract of the Miswak (chewing sticks) used in Jordan and the Middle East on oral bacteria. Int Dent J; 45: 218-22 
[5] Chawla, H. S. 1983. A new natural source for topical fluoride.J Indian Dent Assoc, 55: 419-422

[6] Kubota, K., Tanaka, T., Murata, Y., Hirasawa, M. 1988. Effect of tannic acid on adherence of Candida to denture base.J Dental Research, 67: (suppl) 183

[7] Almas, K. 1993. Miswak (chewing stick) and its role in oral health.Postgrad Dentist Middle East, 3: 214-18

[8] El Mostehy, M. R., Al-Jassem, A. A., Al-Yassin, I. A. 1983. Miswak as an oral health device.Preliminary chemical and clinical evaluation.Hamdard, 26:41-50

[9] Dorner, W. G. 1981. Active substances from African and Asian natural toothbrushes.Chemische Run-dschau, 34: $19-23$

[10] Grant, J. 1990. Miswak- toothbrushes that grow on trees. Todays - FDA, 2: 60

[11] Abo Al-Samh, D., Al-Bagieh, N. 1996. A study of antibacterial activity of the miswak extract in vitro. Biomedical Letters, 53: 225-238

[12] George, E. T., William, C. E. 1985. Pharmacognosy.12th ed. BailliereTindall, p 95

[13] Farooqi, M. I. H., Srivastava, J. G. 1968. The toothbrush tree (Salvadorapersica).Quart.J. Crude Drug Res, 8: 1297-99

[14] Nguelefack, E.M.P., K.P. Ngu, A. Atchade, T. Dimo, N. Tsabang and J.T. Mbafor, 2005. Phytochemical composition and in vitro effects of the ethyl acetate bark extract of DistemonanthusbenthamianusBaillon (Caesalpiniaceae) on Staphylococcus aureus and Streptococcus agalactiae. Cameroon J. Exp. Biol., 1: 50-53

[15] Ndukwe, K. C., Okeke, W., Lamikanra, A., Adesina, S. K., Aboderin, O. 2005. Antibacterial activity of aqueous extracts of selected chewing sticks. J. Contemp. Dent. Pract 6(3): 086-094

[16] Guerrero, M. F., Puebla, P., Martín, M. L., Carrón. San Román, R. L., Reguero, M. T., Arteaga, L. 2002. Inhibitory Effect of N(G)-Nitro-L-arginine Methyl Ester on the Anti-Adrenergic Response Elicited by Ayanin in the Pithed Rat. Planta Med.; 68(4): 322-325

[17] Burkill HM (1985). The useful plants of west tropical Africa.Families A-D.Kew.Royal Botanic Garden.Vol. 1: 254 -257

[18] Onyeyili PA (2000). Anthelmintic Efficacy of some Plants used in Ethnoveterinary Practices in the Arid Zone of North Eastern Nigeria. RGA No. 28, Project Report. pp. 21

[19] Hollist, N.O. (2004). AkojoOogunIbile Yoruba fun awonAisanEnuatiEyin: A Collection of Traditional Yoruba Oral and Dental Medicaments. Bookbuilders, Ibadan

[20] Ajanohoun JE, Ahyi MRA, Ake-Assi, L. 1993. Traditional Pharmacopoeia: Contribution to Ethnobotanical and Floristic Studies in Uganda. Lagos: OAU/STRC

[21] Anokbonggo, W. W., Odoi-Adome, R., Oluju, P. M. 1990. Traditional methods of diarrhoeal management in Uganda. Bulletin of the World Health Organisation;68:359-363

[22] Watt, J. M., Breyer-Brandiwijk, M. G. 1962. Medicinal and Poisonous Plants of Southern and Eastern Africa.2nd Edition. London: E and S Livingstone
[23] Buada, C. V. and Boakye - Yiadom, K. (1973). The antibacterial activity of some Ghanian chewing sticks. Ghana pharmaceutical Journal 1: $150-151$

[24] Rotimi, V. O., Laughon, B. E., Bartlett, J. G. 1998. Activities of Nigerian chewing stick extracts against Bacteroidesgingivalis and Bacteroidesmelaninogenicus. Antibacterial Agents and Chemotherapy; 32(4):598-600

[25] Akande, J. A., Hayashi, Y. 1998. Potency of extract contents from selected tropical chewing sticks against Staphylococcus aureusand Staphylococcuauricularis. World J. Microbiol.andBiotechnol. 14:235-238

[26] Ugoji, E; Egwari, L. O.; and Obisesan, B. (2000). Antibacterial activities of aqueous extracts of ten African chewing sticks on oral pathogens. Nig. Journal of Internal medicine $3(1): 7-11$

[27] Rotimi, V. O., Mosadomi, H. A. 1988. The effect of crude extracts of nine African chewing sticks on oral anaerobes. J Med Microbiol; 23: 55-60

[28] Sofowora, E. A. 1993. Medicinal Plants and Traditional Medicine in Africa. Ibadan - Oweri - Kaduna - Lagos: Spectrum Books Limited; pp. 159-176.pp. 179-189.pp. 195-238

[29] Sofowora, E. A., Isaac-Sodeye, W. A., Ogunkoya, L. O. 1975. Isolation and characterisation of an anti-sickling agent from Fagarazanthoxyloides root. Lloydia. 1975;38:169-171

[30] Taiwo, O., Xu, H. X., Lee, S. F. 1999, Antibacterial activities of extracts from Nigerian chewing sticks. Phytother Res; 13: $675-9$.

[31] Ogwal-Okeng, J. W. 1990. The in vitro Study of the Anhelmintic Activity of Crude Extracts of Two Ugandan Medicinal Plants: Cissusadenocaulis and Fagarazanthoxyloides. Makerere University; M.Sc. Thesis

[32] El-Said, F., Fadulu, S., Kuye, J., Sofowora, E. A. 1971. Native cures in Nigeria, II. The antimicrobial properties of the buffered extracts of chewing sticks.Lloydia, 34: 172-1 74

[33] Oriowo, M. A. 1982. Anti-inflammatory activity of piperonyl-4-acrylic isobutyl amide, an extractive from Zanthoxylumzanthoxyloides.PlantaMedica; 44(1):54-56

[34] Yigit, N,.Aktas, E, and Ayyildiz, A. (2008). Antifungal activity of toothpastes against oral Candida isolates. Journal de MycologieMédicale.18, 141-146

[35] Ogundiya, M. O., Okunade, M. B., Kolapo, A. L. 2006. Antimicrobial activities of some Nigerian Chewing sticks http://www.siu/ebl/leaflets

[36] Adekunle, A. A., Odukoya, K. A. (2006). Antifungal Activities of Ethanol and Aqueous Crude Extracts of Four Nigerian Chewing Sticks. EthnoBotanical Leaflet http://www.siu/ebl/leaflets

[37] Okunade, M. B., Adejumobi, J. A., Ogundiya, M. O., Kolapo, A. L. 2007. Chemical, Phytochemical compositions and antimicrobial activities of some local chewing sticks used in South Western Nigeria.Journal Phytopharmacotherapy and Natural products 1(1): 49-52

[38] Wolinsky, L. E., Sote, E. O. 1983. Inhibiting effect of aqueous extracts of eight Nigerian chewing sticks on bacterial 
properties favouring plaque formation.Caries Research $17: 253-257$

[39] Ingham, J. L., 1973. Disease resistance in higher plants.The concept of pre-infectional and post-infectional resistance. Phytopathol., 78: 314-335

[40] Osbourn,,A.E. 1996. Preformed antimicrobial compounds and plant defense against fungal attack. The Plant Cell, 8: $1821-1831$

[41] Abd El Rahman, H.F., N. Skaug and Whyatt, A. 2003.Volatile compounds in crude Salvadorapersicaextracs. Pharm. Biol., 41: 392-404.
[42] Stuffness, M. and Douros, J. 1982. Current status of the NCI plant and animal product program. J. Nat. Prod., 45: 1-14

[43] Baker, J.T., R. P. Borris, B. Carte, G. A. Cordell, D. D. Soejarto, G. M. Cragg, M. P. Gupta, M. M. Iwu, D. R. Madulid and Tyler, V. E. 1995. Natural productdrug discovery and development: Newperspective on international collaboration. J. Nat. Pro., 58: 1325-1357

[44] Cordell, G.A., 1995. Challenging strategies in natural products chemistry.Phytochemistry, 40:1585-1612.

[45] Kerry, B., 2008. Phytotherapy for Periodontal disease and improved oral hygiene (Phytotherapy Review and Commentary) http://www.mediherb.com 